Check for updates

Montreal

Cite this as: $B M J 2021 ; 374: n 2332$

http://dx.doi.org/10.1136/bmj.n2332

Published: 21 September 2021

\title{
Obesity in US children increased at an unprecedented rate during the pandemic
}

\section{Owen Dyer}

The proportion of US children who are overweight or obese, which has climbed steadily for years, surged to unprecedented levels during the pandemic, according to new figures from the Centers for Disease Control and Prevention (CDC). ${ }^{1}$

Among a cohort of 432302 people aged 2-19 years, the rate of body mass index (BMI) increase roughly doubled during the pandemic compared with the period preceding it. The greatest increases were seen in children aged 6-11 and in those already overweight before the pandemic.

The national weight gain will surprise few paediatricians, who have been warning since the pandemic began of the likely effects of reduced physical activity and increased screen time. But the rate of change is striking. The monthly rate of BMI increase nearly doubled, to 1.93 times its pre-pandemic rate. The proportion of US children who are obese was rising by $0.07 \%$ a month before the pandemic, but by $0.37 \%$ a month-five times faster-after the virus appeared.

An estimated $22 \%$ of US children and teens were obese last August, up from 19\% a year earlier. The data shows a "profound increase in weight gain for kids" that is "substantial and alarming," Alyson Goodman, one of the study's authors, told the Associated Press.

Before the pandemic, children who were a healthy weight were gaining an average of $1.55 \mathrm{~kg}$ a year. That rose to $2.45 \mathrm{~kg}$ during the pandemic. In those who were already moderately obese, weight gain rose from $2.95 \mathrm{~kg}$ a year to $5.45 \mathrm{~kg}$ after the pandemic began. In the severely obese, average annual weight gain went from $4 \mathrm{~kg}$ to $6.6 \mathrm{~kg}$.

The CDC's findings echo those of a study published last month using Kaiser Permanente data from southern California, that reported significantly increased weight gain among children and adolescents aged 5-17 years during the pandemic. ${ }^{2}$

A CDC study in March found that in adults under 65 those with severe obesity (BMI $\geq 45 \mathrm{~kg} / \mathrm{m} 2$ ) have died from covid-19 at twice the rate of people with a normal BMI. ${ }^{3}$

US adults have also gained weight rapidly during the pandemic, although the rate of change has not been measured. The CDC reported last week that the number of states in which at least $35 \%$ of residents self-report obesity increased in 2020 from 12 to $16 . .^{4}$ How much of that weight gain is because of covid-19 is unclear. The number had already jumped from nine states in 2018 to a dozen in 2019. It was zero as recently as 2012 .
The four new states with over 35\% obesity are Delaware, Iowa, Ohio, and Texas. They join Alabama, Arkansas, Indiana, Kansas, Kentucky, Louisiana, Michigan, Mississippi, Oklahoma, South Carolina, Tennessee, and West Virginia.

The CDC's adult obesity map ${ }^{5}$ has been updated to reflect the new data but is based on self-reported obesity. The true US adult obesity rate was last measured at $42.4 \%$ in $2018 .^{6}$ There is no significant difference in obesity rate between men and women or between different adult age groups, but prevalence is higher among Hispanic and African Americans.

The US is the world's most overweight large country, with an average BMI of 26.6 in men and 26.5 in women. Its proportion of obese citizens is exceeded only by 10 small Pacific states and by Kuwait.

1 Lange SJ, Kompaniyets L, Freedman DS, et al. Longitudinal trends in body mass index before and during the covid-19 pandemic among persons aged 2-19 years-United States, 2018-2020. CDC Morbidity and Mortality Weekly Report. 17 September 2021. www.cdc.gov/mmwr/volumes/70/wr/mm7037a3.htm.

2 Woolford SJ, Sidell M, Li X, et al. Changes in body mass index among children and adolescents during the covid-19 pandemic. JAMA 2021. https://jamanetwork.com/journals/jama/fullarticle/2783690.pmid:34448817

3 Kompaniyets L, Goodman AB, Belay B, et al. Body mass index and risk for covid-19-related hospitalization, intensive care unit admission, invasive mechanical ventilation, and death-United States, March-December 2020 CDC Morbidity and Mortality Weekly Report. 12 March 2021. www.cdc.gov/mmwr/volumes/70/wr/mm7010e4.htm

4 CDC. Number of states with high obesity prevalence rises to sixteen. CDC. 15 September 2021. www.cdc.gov/media/releases/2021/s0915-obesityrate.html.

5 CDC. Adult obesity prevalence maps. September 2021. www.cdc.gov/obesity/data/prevalence-maps.html\#overall.

6 Hales CM, Carroll MD, Fryar CD, Ogden CL. Prevalence of obesity and severe obesity among adults: United States, 2017-2018. National Center for Health Statistics data brief, February 2020. www.cdc.gov/nchs/products/databriefs/db360.htm. 